\title{
Strategi Media Relations Perusahaan Pertambangan Timah dan Agenda Setting Media di Bangka Belitung
}

\author{
Iswandi Syahputra ${ }^{1}$ \\ ${ }^{1}$ Universitas Islam Negeri (UIN) Sunan Kalijaga Yogyakarta
}

\begin{abstract}
ABSTRAK
Artikel ini menjelaskan strategi media relations yang digunakan oleh perusahaan pertambangan timah di provinsi Bangka Belitung dalam menyusun agenda setting media. Satu sisi, perusahaan pertambangan timah memiliki agenda agar dapat melakukan penambangan sesuai peraturan. Pada sisi lainnya, pemerintah daerah sebagai pihak yang berada di luar institusi media massa dan perusahaan pertambangan juga memiliki agenda tersendiri. Sehingga persoalan pertambangan timah di Bangka Belitung memiliki potensi konflik kepentingan, bukan saja antar perusahaan dengan pemerintah, tetapi juga dengan warga masyarakat. Penelitian ini bertujuan mengetahui bagaimana strategi media relations perusahaan pertambangan timah dalam menyusun agenda setting media massa di Bangka Belitung. Ini merupakan penelitian kualitatif dengan teknik pengumpulan data melalui observasi partisipatoris. Data penelitian ini diperoleh melalui pengamatan dan partisipasi semi tertutup serta wawancara dengan sejumlah informan yang memiliki kompetensi dan relevansi dengan masalah penelitian. Temuan penelitian ini menunjukkan bahwa media massa sebagai institusi ekonomi digerakkan melalui prinsip transaksional. Pada sisi lain, perusahaan penambang timah dan pemerintah daerah memiliki agenda setting bersama. Relasi berbagai sisi tersebut merupakan faktor internal yang terjadi dalam suatu iklim media baru yang sangat dinamis. Sedangkan aktivitas yang sangat dinamis pada era media baru tersebut merupakan faktor eksternal. Relasi antara faktor internal dan eksternal tersebut digambarkan sebagai hal yang dapat menyusun agenda setting media. Agenda setting merupakan teori yang menjelaskan media membentuk agenda khalayak. Sehingga khalayak cenderung menilai suatu hal menjadi penting karena media menilai suatu hal tersebut penting.
\end{abstract}

Kata-kata Kunci: Agenda setting media; bangka belitung; media relations; pertambangan timah; strategi

\section{Media Relations Strategy of Tin Mining Company and Agenda Setting Media in Bangka Belitung}

\begin{abstract}
This article describes the media relations strategy employed by a lead mining company in the Bangka Belitung Province in composing its media agenda-setting. On one hand, the lead mining company has an agenda of being able to conduct mining according to existing regulations. On the other hand, the regional government, as an external organization to mass media institutions and the mining company, has their own agenda. The lead mining issue in Bangka Belitung, thus, has the potential of leading to a conflict of interests, not only between the company and the government, but with the communities as well. This study aims to understand the media relations strategy implemented by the lead mining company in composing its mass media agendasetting in Bangka Belitung. This research is a qualitative research utilizing the participatory method. Data acquired through observations, semi-closed participation, and interviews. The research findings show that mass media as an economic institution had been driven via transactional principles. Moreover, the lead mining company and the regional government had a common agenda-setting. Such relations of various properties are considered as an internal factor that had occurred within a highly dynamic new media climate. Whereas these highly dynamic activities in the current media era are actually regarded as an external factor. The relation between the internal and external factors is described as elements capable of drawing up media agenda setting. Agenda setting is a theory that explains how the media shapes the public's agenda. Hence, if the public were found to have a tendency to consider something as being important, it would be because the media considers it as something important.
\end{abstract}

Keywords: Bangka belitung; media agenda setting; media relations; strategy; tin mining

Korespondensi: Dr. Iswandi Syahputra, M.Si. Fakultas Ilmu Sosial dan Humaniora Unniversitas Islam Negeri (UIN) Sunan Kalijaga Yogyakarta. Jln. Laksda Adisucipto, Daerah Istimewa Yogyakarta 55281. Email: iswandi.syahputra@uin-suka.ac.id 


\section{PENDAHULUAN}

Seiring dengan pesatnya kemajuan komunikasi berbasis perangkat teknologi atau perangkat elektronik, kebutuhan terhadap bahan baku perangkat komunikasi elektronik juga mengalami peningkatan. Salah satu bahan baku yang dibutuhkan untuk merakit perangkat komunikasi seperti komputer dan gadget adalah bahan logam jenis timah. Bahan baku timah berguna sebagai saluran yang akan mengantarkan power dalam satu sistem rakitan perangkat komunikasi. Menurut catatan Mongabay Indonesia (2013), sejumlah perusahaan besar perakit perangkat komunikasi di dunia seperti Nokia, Sony, Motorola, LG, dan Blackberry membutuhkan timah sebagai salah satu bahan baku utama dalam merakit perangkat komunikasi yang mereka produksi (Mongabay, 2013, Agustus 5).

Timah menjadi pilihan ekonomis karena harganya lebih murah dibanding logam lainnya seperti perak atau emas. Perusahaan elektronik besar dunia tersebut mengaku menggunakan bahan baku timah dari Indonesia. Di dunia, Indonesia memang dikenal sebagai salah satu negara penghasil timah terbesar setelah Cina. Menurut laporan Pusat Data dan Teknologi Informasi Kementerian Energi dan Sumber Daya Manusia (dalam Pamudji, 2016) potensi timah di Indonesia sekitar 99\% berada di Kepulauan Bangka Belitung, dan sisanya tersebar di wilayah Riau, Kepulauan Riau dan Kalimantan Barat. Total sumber daya timah Indonesia dalam bentuk bijih sebesar 3.483.785.508 ton dan logam 1.062.903 ton.

Hingga saat ini, proses pertambangan timah di Provinsi Bangka Belitung masih terus berlangsung. Pertambangan tersebut dilakukan oleh sejumlah perusahaan swasta dan perusahaan milik negara. Sejumlah perusahaan pertambangan timah di Provinisi Bangka Belitung sangat strategis sebagai salah satu sektor pemasukan dan peningkatan pendapatan negara. Namun pada saat yang bersamaan, berbagai perusahaan pertambangan tersebut merupakan pihak yang paling bersentuhan langsung dengan berbagai potensi konflik dengan masyarakat awam yang juga banyak menggantungkan hidupnya pada Tambang Konvensional (TI). Potensi tersebut menjadi lebih terbuka pada era media saat ini. Media (baik media massa maupun media sosial) menjadi sektor khusus yang mengambil peran penting dalam setiap dinamika sosial yang terkait dengan pertambangan. Pandangan ini kemudian membutuhkan satu strategi media relations yang khusus dari perusahaan pertambangan.

Sebagai salah satu aktivitas dalam lingkup public relations, media relations merupakan bagian dari public relations eksternal yang membina dan mengembangkan hubungan baik dengan media massa sebagai sarana komunikasi antara organisasi dengan publik untuk mencapai tujuan organisasi (Iriantara, 2010). Media relations menjadi kunci untuk mengoptimalkan pesan perusahaan dengan pihak di luar perusahaan (eksternal) seperti masyarakat, pengguna hingga dunia internasional maupun pihak di dalam perusahaan (internal) seperti Pemerintah dan pihak terkait lainnya (Vivian, 2017). Optimalisasi pesan perusahaan sebagai agenda yang hendak disampaikan pada khalayak eksternal dan internal tersebut menjadi hal mendasar yang akan menentukan strategi yang akan digunakan dalam relasi dengan media massa.

Strategi media relations menjadi sangat penting bagi perusahaan yang bergerak dalam sektor pertambangan karena memiliki potensi konflik sosial, dan konflik lingkungan. Tanpa strategi media relations yang baik, potensi konflik dapat mengarah pada fase krisis. Riset yang dilakukan Hernawan dan Muniroh (2014) menjelaskan perusahaan pertambangan PT. Bukit Asam (Persero) Tbk dapat memiliki citra positif melalui tiga proses komunikasi, yaitu komunikasi massa, komunikasi kelompok dan komunikasi interpersonal. Tentu saja citra positif tersebut pada perusahaan dalam keadaan normal. Padahal mengacu pada riset Febriyansyah, Christin dan Imran (2016), aktivitas humas pada masa normal berbeda dengan aktivitas humas pada masa krisis. Pada saat hadapi krisis, humas PT. Pelabuhan Tanjung Priok yang diteliti, tidak ikut berkontribusi dalam penanggulangan krisis. Humas hanya menyebarkan informasi yang positif dan benar kepada media cetak maupun elektronik. Sementara mengacu pada Rahmat dan Bakti (2016), aktivitas Humas pemerintah dinilai tertumpu pada kegiatan rutin. Humas hanya menyediakan informasi bagi media. Riset tersebut menunjukkan bahwa aktivitas media relations pada saat krisis dan saat normal bidang Humas tidak memiliki strategi yang terencana 
sebagai agenda setting korporasi (institusi).

Dalam perspektif ini, agenda setting media akan bertemu dengan agenda setting perusahaan pertambangan. Dengan demikian, penelitian ini menawarkan perspektif baru dalam kajian agenda setting media. Teori agenda setting media pertama kali digagas oleh Maxwell McCombs dan Donald Shaw (dalam Griffin, 2015). Riset yang mereka lakukan tentang Watergate (1972) merupakan awal dari berfungsinya agenda setting media massa. Pada prinsipnya, agenda setting media bekerja membentuk agenda khalayak menjadi seperti hal yang penting berdasarkan informasi yang mereka terima melalui media massa. Khalayak cenderung menilai suatu hal menjadi penting karena media menilai suatu hal tersebut penting (McCombs, 2016).

Namun, perkembangan teknologi komunikasi yang pesat saat ini turut memberi pengaruh pada pemaknaan agenda setting media. Bila sebelumnya agenda setting media muncul pada tradisi media massa konvensional, namun saat ini penyerapan dan konsumsi informasi telah dimediasi oleh suatu sistem komunikasi berbasis Internet. Kehadiran Internet yang pesat saat ini telah memunculkan gagasan tentang media baru (new media). Penggunaan istilah media baru menjadi penanda imajiner berakhirnya tradisi media lama yang sering dilekatkan pada media massa berbasis mesin cetak.

Perkembangan teknologi yang selalu menyertai perkembangan komunikasi termasuk perkembangan media di dalamnya tersebut juga memberi pengaruh pada perkembangan agenda setting media yang sudah ada sebelumnya. Sebagai penggagas agenda setting media, Maxwell McCombs sendiri kemudian melakukan review teoretik terhadap gagasan agenda setting media yang pernah mereka usung. Tinjauan ulang terhadap gagasan agenda setting media dilakukan dengan mengidentifikasi kembali beberapa perubahan situasi karena kehadiran media baru berbasis Internet tersebut. Hasilnya, McCombs menawarkan second level agenda-setting atau agenda setting level kedua (McCombs, 2005).

Second level agenda-setting ini menjelaskan bagaimana proses penyusunan agenda media berhubungan dengan proses framing. Proses framing media menjelaskan bahwa media tidak saja menyampaikan berita berdasarkan fakta peristiwa, tetapi menonjolkan hal khusus dari satu peristiwa berdasarkan agenda media. Sedangkan publik menyusun agenda mereka berdasarkan informasi yang mereka peroleh dari berbagai jenis media seperti koran, radio, televisi, media daring, termasuk media sosial. Padahal pada era media baru, khalayak bukan pihak yang pasif menerima informasi seperti pada tradisi media konvensional. Khalayak pada media baru adalah khalayak yang aktif dan interaktif, mereka konsumen sekaligus dapat bertindak sebagai produsen informasi bahkan tanpa melalui mekanisme gatekepeer sama sekali. Perubahan karakter media dan khalayak ini yang turut menentukan bagaimana agenda publik tersebut dibentuk. Dengan uraian tersebut, artikel ini bermaksud menjawab masalah utama penelitian, yaitu untuk mengetahui strategi media relations perusahaan pertambangan timah dalam menyusun agenda setting media di Bangka Belitung.

\section{METODE PENELITIAN}

Penelitian ini menggunakan pendekatan kualitatif. Penelitian dilakukan di Bangka dan Belitung pada bulan Agustus dan September 2017. Objek penelitian ini adalah strategi media relations. Sedangkan subjek penelitian adalah Humas perusahaan pertambangan timah di provinsi Bangka Belitung. Data penelitian ini dikumpulkan dengan pengamatan dan partisipasi semi tertutup serta wawancara. Mengacu pada Bodgan dan Steven (1998) berdasarkan tingkat keterlibatan peneliti dalam observasi yang dilakukan, observasi dapat dikategorikan kedalam dua kelompok: observasi tidak terlibat (non participant observation), observasi terlibat (participant observation); dan berdasarkan tingkat kerahasiaan pelaksanaannya, observasi terbagi kedalam dua kelompok lain yaitu observasi terang-terangan (obstrusive observation) dan observasi tersamar (unobtrusive observation).

Secara khusus, data penelitian diperoleh dengan melakukan wawancara informal dan tidak terstruktur dengan 4 staf humas perusahaan pertambangan. Kriteria untuk menjadi informan dalam penelitian ini adalah telah bekerja sebagai staf humas minimal satu tahun, memiliki kemampuan dasar kehumasan (seperti menulis press release), dan pernah berinteraksi dengan media massa (wartawan). 
Data yang diperoleh selanjutnya dianalisis dalam bentuk diskripsi melalui suatu proses pemaknaan (meaning making) dan pemahaman (verstehen/ understanding). Secara teknis proses tersebut dapat dimulai dari mencari dan menemukan peristiwa yang relevan dengan permasalahan penelitian. Kemudian dielaborasi dalam sejumlah kategori-kategori konseptual. Selanjutnya menemukan tema antar kategori dan mengintegrasikannya ke dalam gagasan yang memiliki struktur argumentatif (Wimmer dan Dominick, 2014).

\section{HASIL DAN PEMBAHASAN}

Kendati cukup strategis sebagai pihak yang bekerja membentuk dan menjaga citra positif perusahaan, namun fungsi Humas saat ini masih sebagai teknisi komunikasi seperti membuat press release, menggelar press conference (Farihanto, 2014; Ardhoyo, 2013), fasilitator komunikasi (Astuty, dkk, 2017; Idris, 2014; Lubis, 2012; Yuningsih, 2006), fungsi komunikasi oraganisasi (Ishak, 2012) atau monitoring media massa (Bernadeth, Paranoan, dan Djumlani, 2014). Sementara itu, kondisi Humas korporasi saat penelitian pertambangan timah di Bangka Belitung yang diteliti menggambarkan sebuah organisasi dalam korporasi yang menjalankan dua fungsi. Mengacu pada riset yang dilakukan oleh Glen Broom dan David Dozier (dalam Theaker, 2012) Humas pada sebuah korporasi menjalankan dua fungsi utama yaitu, sebagai teknisi komunikasi dan manajer komunikasi. Sebagai teknisi komunikasi, Humas bekerja melakukan hal-hal teknis dalam beberapa aktivitas kehumasan seperti membuat press release, menyelenggarakan konferensi pers, media briefing dan sebagainya. Sedangkan sebagai manajer komunikasi, Humas merupakan satu unit manajemen dalam sebuah struktur korporasi.

Dalam perspektif tersebut, Humas adalah satu bidang dalam sebuah struktur korporasi yang menjalankan empat fungsi utama, yaitu (1) the expert prescriber, yaitu pihak yang diberi (memiliki) otoritas oleh manajemen korporasi untuk menjalankan aktivitas komunikasi korporasi. Aktivitas kehumasan tersebut dapat mulai dari meneliti, merumuskan, menjalankan dan mengembangkan berbagai model komunikasi terhadap publik internal dan eksternal korporasi baik dalam situasi normal dan krisis. (2) the problem-solving facilitator, yaitu pihak yang terlibat dalam melakukan analisis dan merumuskan solusi strategis terhadap berbagai masalah yang dihadapi oleh korporasi. (3) the communication facilitator, yaitu pihak yang menginterpretasikan visi dan misi korporasi untuk kemudian mengkomunikasikannya pada khalayak luas. Humas merupakan representasi korporasi yang terlibat aktif menjadi mediator dan fasilitator komunikasi korporasi dan khalayak. (4) the communication technician, yaitu pihak yang memiliki kemampuan soft skill seperti menulis press release dan menggunakan kemampuan tersebut untuk kepentingan korporasi. Dalam konteks ini, Humas bukan pihak yang terlibat dalam proses mengambil kebijakan perusahaan, tetapi memiliki tugas teknis menyebarluaskan kebijakan korporasi.

Dalam konteks tersebut, mengacu pada Cutlip, Center, dan Broom, (2009) bidang Humas merupakan pihak yang menjalankan fungsi manajemen. Fungsi tersebut bekerja mendukung proses penyelarasan pemahaman berupa saling memberi dan menerima dengan penuh saling pengertian dan semangat kerjasama antara bidang dalam korporasi menuju tujuan bersama korporasi. Namun dalam praktiknya, praktisi Humas kebanyakan hanya menjalankan banyak peran dalam satu waktu yang bersamaan (Broom dan Dozier dalam Theaker, 2012).

Perspektif tersebut menggambarkan kondisi Humas saat ini pada perusahaan pertambangan timah yang diteliti. Pada satu sisi Humas merupakan bidang dalam struktur manajemen. Namun pada sisi lainnya stafHumas menjalankan banyak peran dalam satu waktu yang bersamaan. Penelitian ini menemukan setiap staf Humas memiliki kemampuan dasar menulis press release. Mengacu pada informan 1, kemampuan tersebut berbeda berdasarkan minat pada topik berita yang akan diproduksi. Akibatnya, satu jenis pekerjaan dapat dilakukan oleh banyak staf Humas.

"Setiap staf Humas memiliki kemampuan dasar menulis press release. Namun demikian, kemampuan tersebut berbeda sesuai minat dan bakat menulis setiap orang. Ada staf Humas yang memiliki kemampuan cukup baik dalam menulis release untuk berita atau peristiwa yang memiliki dimensi kemanusiaan. Staf 
dengan keahlian ini digunakan untuk membuat press release aktivitas Humas yang berhubungan dengan CSR. Namun ada juga staf Humas yang suka menulis tema yang terkait analisis kebijakan. Staf dengan minat seperti ini biasanya menulis release terkait dengan kebijakan perusahaan atau merangkum sambutan Direktur Utama dan jajaran Direksi dalam bentuk press release. Sehingga pembuatan press release bisa diserahkan pada minat terhadap topik masing-masing staf Humas atau sesuai dengan penugasannya" (Informan 1, Wawancara 25 Juli 2017).

Kondisi tersebut bukan saja menjelaskan bahwa Humas menjalankan banyak peran dalam berbagai situasi yang berbeda. Namun kemampuan dasar yang dimiliki oleh staf Humas tersebut pada prakteknya membawa aktivitas Humas pada umumnya pekerja teknis sebagai the communication technician. Namun demikian, dari pengamatan silang yang dilakukan terhadap pejabat Humas yang memiliki struktur lebih tinggi, perusahaan menyadari bahwa Humas sebagai pihak yang menjalankan fungsi manajemen yang bekerja mendukung proses penyelarasan pemahaman berupa saling memberi dan menerima dengan penuh saling pengertian dan semangat kerjasama antara bidang dalam korporasi menuju tujuan bersama korporasi.

Mengacu pada informan 2, bidang Humas diberikan keleluasaan untuk merancang sendiri strategi komunikasi yang akan mereka tempuh untuk menunjang kebijakan korporasi.

"Manajemen memberikan keleluasaan pada Humas untuk merancang sendiri strategi komunikasinya. Namun karena perusahaan memiliki sejumlah bidang atau divisi lain yang terkait dengan pekerjaan Humas seperti CSR, kami juga tidak bisa merumuskannya secara otonom. Kami harus terlebih dahulu melakukan komunikasi internal. Misalnya untuk aktivitas CSR yang bersentuhan langsung dengan masyarakat, pemberitaannya kami himpun dalam satu majalah khusus yang kami produksi sendiri. Sementara untuk relasi dengan media massa setempat kami gunakan cara yang sudah berjalan sebelumnya" (Informan 2, Wawancara 28 Juli 2017).
Dalam perspektif level struktur ini, Humas menjalankan fungsi the expert prescriber, sebagai pihak yang memiliki otoritas oleh manajemen korporasi untuk menjalankan aktivitas komunikasi korporasi. Namun berdasarkan pengamatan dan partisipasi semi tertutup serta wawancara yang dilakukan, dalam hal membangun relasi dengan media massa setempat pada konteks pemberitaan terhadap aktivitas perusahaan ditemukan 2 pola, yaitu:

Pertama, Humas mengundang media massa terutama media massa cetak dan media massa daring untuk melakukan liputan aktivitas perusahaan yang dipilih. Setiap wartawan yang hadir diberi imbalan biaya transportasi. Kondisi ini sudah berlangsung lama dan efektif meningkatkan jumlah pemberitaan. Relasi antara Humas dan media massa menjadi bersifat transaksional. Namun pola ada biaya, ada berita tidak sepenuhnya dapat berlangsung sejalan sebagai proses sebab-akibat. Sebab tidak semua media yang hadir kemudian diberi biaya transportasi memberitakan aktivitas perusahaan. Atau, tidak seluruh berita yang muncul menyajikan nilai positif bagi perusahaan.

Kedua, Humas menyusun press release dalam bentuk pressklaar (naskah press release siap naik sebagai berita) suatu aktivitas. Press release tersebut kemudian dikirim pada media massa yang sudah memiliki hubungan baik yang terbentuk berdasarkan pola pertama. Selanjutnya media massa bersangkutan memuat berita yang mereka terima.

Kedua pola tersebut berjalan tanpa dasar adanya suatu desain agenda setting yang diinginkan oleh perusahaan. Aktivitas perusahaan hanya membutuhkan publikasi media massa. Padahal, sebagai perusahaan dalam sektor pertambangan sering berkaitan dengan berbagai potensi konflik, seperti konflik sosial, konflik lingkungan atau konflik politik (regulasi). Pada sisi lain, liberalisasi media massa yang terjadi sebagai dampak demokratisasi telah membentuk kultur konglomerasi dalam industri media massa. Pertumbuhan media massa demikian cepat berjaringan dalam kelompok perusahaan besar (Syahputra, 2013). Tidak hanya itu, kemajuan teknologi komunikasi berbasis Internet juga telah mendorong munculnya sejumlah portal berita. Kondisi tersebut memicu kompetisi yang mendorong terjadinya praktik jurnalistik jalan pintas. 
Kendati awalnya tidak ada desain untuk menyusun agenda setting perusahaan, namun potensi konflik (sosial dan politik) dalam sektor pertambangan dan liberalisasi yang bersifat transaksional dalam sektor media massa lokal dijadikan dasar untuk menyusun agenda setting perusahaan. Kondisi ini kemudian dilihat oleh Humas perusahaan sebagai peluang untuk menyusun agenda perusahaan dan menjadikannya sebagai agenda media massa. Dengan demikian diharapkan agenda media massa yang memuat agenda perusahaan dapat menjadi agenda publik untuk selanjutnya dapat mempengaruhi agenda kebijakan pemerintah. Dalam praktiknya, agenda setting perusahaan merupakan strategi komunikasi perusahaan dalam membangun relasi baru dengan media massa cetak dan media massa daring.

Mengacu pada informan 3, ada tiga hal yang dijadikan dasar dalam menyusun agenda setting sebagai strategi komunikasi koorporasi. Pertama, pertambangan timah masih menyimpan potensi konflik laten. Kedua, praktek pemberitaan media massa dinilai masih bersifat transaksional. Ketiga, media massa tidak memiliki fokus agenda setting media bersama.

"Di sini kandungan timahnya masih banyak, harga timah dunia juga lagi naik. Kondisi ini sangat baik untuk menambang timah. Hasilnya nanti kembali untuk kesejahteraan masyarakat, daerah dan nasional. Dengan teknik atau metode tambang yang ramah lingkungan, sebenarnya tidak ada masalah. Tapi kami juga memahami belum semua masyarakat bisa mengetahuinya. Potensi konflik pertambangan timah masih ada tapi terpendam. Masyarakat yang belum paham ini perlu diberi pemahaman. Bagaimana menambang tidak bertentangan dengan nelayan, atau pariwisata? Maka dibutuhkan satu aturan tentang zonasi yang menguntungkan semua pihak. Bagaimana aturan tentang zonasi ini diterima sebagai kebaikan bersama? Caranya melalui penyebaran informasi melalui media massa. Media massa menjadi strategis sebagai perantara karena media sendiri belum memiliki fokus agenda bersama terhadap tambang. Selain ini, pada prakteknya media juga institusi bisnis yang bersifat transaksional" (Informan 3, Wawancara 2 Agustus 2017).
Informasi tentang media massa belum memiliki agenda bersama terhadap persoalan pertambangan di Bangka Belitung ini menjelaskan bahwa sebagai institusi ekonomi media atau konglomerasi media memiliki kepentingan yang berbeda (Setyowati, 2011; Pramono, 2016; Yustisia, 2010; Sarohmawati, dan Ashaf, 2017). Selain itu, hal ini juga dapat dijelaskan oleh adanya perbedaan kepentingan ideologis media dapat berpengaruh agenda setting media (Pembayun, 2015; Maman, Kartini, dan Yuningsih, 2016).

Informan 4 juga menjelaskan, potensi konflik yang bersifat laten ini disebabkan oleh beberapa faktor antara lain disebabkan oleh ketidakadilan sosial pada masa lalu saat tambang timah masih menjadi primadona pendapatan daerah. Selain itu masih ada presepsi pada khalayak bahwa proses pertambangan timah akan mencemari lingkungan dan mengancam pekerjaan masyarakat sebagai nelayan atau petani lada. Tidak hanya itu, masyarakat yang mulai menaruh harapan hidup mereka pada sektor pariwisata menganggap pertambangan timah dapat mengganggu aktivitas pariwisata.

"Masyarakat merasa ditinggal oleh perusahaan tambang timah setelah ada krisis moneter tahun 1998 lalu. Pada masa tambang timah masih berjaya pada era Orde Baru, tidak seluruh lapisan masyarakat merasakan manfaatnya. Kemudian datang krisis, sebagian rakyat mulai beralih pada sektor pariwisata. Sebagian lain memilih bertani lada dan sebagian lain tetap menambang yang dilakukan secara inkonvensional. Saat ini ketika timah memberikan harapan baru karena masih tersimpan dalam jumlah besar dengan harga jual tinggi, ada potensi resistensi untuk ditolak sehingga memang ada potensi laten konfliknya. Masalah tambang, pariwisata, lingkungan dan nasib nelayan atau petai menjadi hal pelik yang sulit untuk diurai" (Informan 4, Wawancara 3 Agustus 2017).

Informasi dari informan 4 tersebut menunjukkan bahwa pertambangan timah mengandung potensi konflik kepentingan yang tersusun dari persepsi-persepsi berdasarkan informasi yang menyebar bebas, baik melalui media massa maupun perbincangan antar warga. Persepsi khalayak ini kemudian terpolarisasi menjadi sikap sosial yang pro dan kontra. 
Mengacu pada Pruitt dan Rubin (1986), konflik memang merupakan persepsi kelompok sosial terhadap perbedaaan kepentingan (perceived divergen of interest). Sebagian khalayak masih memiliki presepsi negatif pada pertambangan timah. Persepsi sebagian khalayak tersebut kemudian dapat berkembang menjadi opini publik yang melibatkan lebih banyak lapisan masyarakat lainnya. Proses tersebut kemudian termediasi melalui media massa, terlebih lagi melalui media sosial atau media daring.

Selanjutnya menurut Pruitt dan Rubin (1986) komunikasi melalui media dapat mendorong berbagai kepentingan laten (dalam riset ini baik yang tersembunyi sebagai agenda media, agenda perusahaan tambang atau sebagai agenda khalayak) terebut muncul ke permukaan sebagai agenda bersama. Disadari atau tidak, saat orang membaca atau memperoleh informasi dari media (media massa, media daring atau media sosial) kemudian membicarakannya pada orang lain, maka kepentingan latennya muncul sebagai suatu kesadaran.

Hasil akhirnya dapat membentuk struggle group. Struggle group ini sangat potensial bertindak sebagai inisiator konflik. Mereka bisa sangat impresif dengan sengaja mencari kelompok yang berbeda bukan untuk berdiskusi tetapi memancing konflik. Konflik dipilih sebagai metode menyelesaikan masalah atau memperjuangkan kepentingan kelompok. Mengacu pada Dahrendorf (dalam Pruitt dan Rubin, 1986) ada tiga kondisi yang dapat memunculkan struggle group. Pertama, adanya komunikasi yang intensif dari orang yang merasa senasib. Kedua, adanya pemimpin kelompok yang dapat merumuskan kepentingan bersama dan mengorganisasikannya dalam berbagai bentuk tindakan. Ketiga, adanya pengakuan atau legitimasi dari masyarakat yang lebih luas.

Dalam riset ini, potensi menjadi struggle group identik dapat diidentifikasi pada kelompok Forttal (Forum Rakyat Tolak Tambang Laut) di Belitung. Forttal merupakan kelompok masyarakat di Belitung yang menolak adanya tambang laut dengan alasan merusak lingkungan atau mengancam nasib nelayan (Forttal gelar aksi damai tolak tambang laut, 5 Agustus 2013) Mengacu pada Dahrendorf (dalam Pruitt dan Rubin, 1986) tentang tiga kondisi yang dapat memunculkan struggle group, dan berdasarakan pengamatan silang yang dilakukan, aktivitas Forttal baru memasuki kondisi pertama, adanya komunikasi yang intensif dari orang yang merasa senasib. Menurut informan 5, Forttal tidak mendapat dukungan luas dari masyarakat nelayan karena mereka sendiri bukan nelayan.

"Forttal ini seperti LSM (Lembaga Swadaya Masyarakat) yang berjuang menolak tambang laut karena alasan lingkungan dan membela nasib nelayan. Tapi mereka tidak memiliki dasar kajian untuk mendukung sikap tersebut. Selain itu masyarakat nelayan juga tidak merasa diwakili oleh mereka. Mereka hanya merasa senasib karena pada masa lalu pernah dirugikan oleh pertambangan timah. Perasaan senasib tersebut dimanfaatkan secara politik oleh pihak lain yang juga ingin melakukan penambangan timah. Jadi situasinya memang agak kusut. Ada persaingan antar perusahaan pertambangan timah" (Informan 3, Wawancara 2 Agustus 2017).

Informasi tersebut menunjukkan bahwa potensi konflik dalam pertambangan timah menjadilebihpelikkarenamelibatkan persaingan internal antar perusahaan pertambangan. Namun demikian hal ini menegaskan bahwa sesama perusahaan pertambangan dapat saling menguatkan untuk menyusun agenda bersama mereka. Agenda bersama tersebut menjadi penting agar mereka dapat melakukan aktivitas pertambangan yang dapat diterima dan mengakomodasi seluruh kepentingan pihak yang terkait dengan pertambangan.

Berbagai relasi kepentingan dalam situasi yang kompleks tersebut dicermati dengan teliti oleh Humas sebelum menyusun strategi komunikasi yang akan mereka pilih. Mengacu pada informan 1, Humas tidak lagi sekedar menjalankan fungsi sebagai teknisi komunikasi, tetapi menjalankan fungsi manajemen komunikasi. Sebagai fungsi manajemen komunikasi, Humas telah melakukan the expert prescriber dengan mulai meneliti, merumuskan, menjalankan dan mengembangkan berbagai model komunikasi terhadap publik eksternal korporasi. Humas juga melakukan fungsi the problem-solving facilitator, yang terlibat dalam melakukan analisis dan merumuskan solusi strategis terhadap berbagai masalah yang dihadapi oleh korporasi. Fungsi the communication facilitator, yang menginterpretasikan visi dan misi korporasi 
untuk kemudian mengkomunikasikannya pada khalayak luas.

Keseluruhan aktivitas Humas tersebut (the expert prescriber, the problem-solving facilitator dan the communication facilitator) kemudian menjadi satu strategi komunikasi dalam konteks media relations. Dalam perspektif ini, hal pertama yang dilakukan Humas adalah memahami dengan baik visi dan misi perusahaan sebagai kultur korporasi. Perusahaan berkeinginan melakukan penambangan timah dengan resiko konflik minimal. Beberapa potensi konflik yang muncul telah diantisipasi melalui kebijakan korporasi. Misalnya, metode penambangan dengan orientasi ramah lingkungan. Pertambangan yang akan dilakukan dikembalikan pada kesejahteraan masyarakat, dan melindungi masyarakat adat. Hal ini mengacu pada informan 1 :

"Kandungan timah di sini masih menjanjikan untuk dilakukan penambangan. Jika ditambang dengan metode ramah lingkungan dan ramah sosial, tentu manfaatnya lebih besar bagi masyarakat dan sumber penghasilan bagi pemerintah daerah. Prinsipnya proses penambangan timah sesuai regulasi, selaras dengan aspirasi masyarakat dan dampaknya dapat dirasakan langsung oleh semua pihak. Karena itu berbagai potensi konflik sedapat mungkin dihindari dengan mematuhi seluruh prosedur yang sudah diatur dalam berbagai regulasi" (Informan 1, Wawancara 25 Juli 2017).

Selanjutnya, hal kedua yang dilakukan Humas adalah mencermati dengan seksama kultur media, baik media massa cetak, media massa daring maupun aktivitas di media sosial. Dalam perspektif ini, mengacu pada informan 1, Humas korporasi menilai proses pemberitaan oleh media massa lokal masih diwarnai praktik transaksional. Selain itu, pola pemberitaan media terhadap tambang dinilai masih berbasis peristiwa. Atau dengan kata lain, media massa belum memiliki agenda bersama dalam menghadapi aktivitas pertambangan timah.

"Hal ini (pemberitaan transaksionalpeneliti) terkadang merepotkan kami. Sebab kami sebenarnya ingin wartawan bekerja sesuai kode etik untuk mencari dan mengolah berita yang bermanfaat bagi publik sesuai prinsip jurnalistik. Sebagai institusi bisnis, transaksi dengan media tetap bisa dilakukan melalui kerjasama iklan. Pada era keterbukaan ini kami juga ingin perusahaan mendapat citra positif di mata masyarakat. Pada praktiknya memang ada biaya yang kami keluarkan untuk iklan dan aktivitas media relations lainnya. Dalam konteks ini, wartawan adalah mitra kami. Mereka butuh berita, kami butuh publisitas. Relasi ini kami lihat sebagai peluang untuk menyusun agenda perusahaan agar dapat menjadi berita dan agenda media" (Informan 1, Wawancara 25 Juli 2017).

Proses pencermatan dua hal tersebut kemudian dikaji kembali hingga mengarah pada pilihan strategi yang akan dilakukan. Maka berikutnya hal ketiga yang dilakukan Humas adalah merumuskan sektor apa saja yang paling berpotensi besar menimbulkan konflik pertambangan. Rumusan tersebut mengacu pada visi dan misi korporasi dan situasi atau kultur media. Pada sisi lain, konflik pertambangan dapat muncul dari berbagai sektor seperti lingkungan, keadilan sosial, persaingan bisnis atau perlindungan terhadap budaya lokal. Potensi konflik tersebut secara mendasar disadari oleh pemerintah pusat dan pemerintah daerah. Untuk mengakomodasi semua aspirasi agar terhindar dari berbagai konflik, pemerintah menyusun suatu rancangan Peraturan Daerah (Perda) tentang Zonasi Wilayah Pesisir dan Pulau-pulau Kecil (WP3K) sebagai turunan dari Undang-undang Nomor 27 tahun 2007 tentang pengelolaan Wilayah Pesisir dan Pulau-pulau Kecil (WP3K) yang diatur dalam pasal 7 ayat 1 .

Sementara bagi korporasi pertambangan timah, Perda zonasi ini adalah jaminan hukum untuk menciptakan iklim investasi dan kepastian hukum dalam usaha pertambangan. Mengacu pada informan 2 yang menilai Perda zonasi merupakan solusi terbaik untuk menekan bahkan menghilangkan potensi konflik yang dapat muncul dari berbagai sektor.

"Perda zonasi menjadi penting, bukan saja untuk alasan mengakomodasi berbagai kepentingan, tetapi menjadi dasar hukum yang dipatuhi bersama. Tambang, lingkungan dan pariwisata dapat berjalan bersama menjadi kekuatan sinergis melalui suatu pengaturan berbasis zona masingmasing. Misalnya, menambang tidak boleh 
di kawasan pariwisata atau kolong (bekas lobang galian tambang-peneliti) harus direklamasi menjadi area produktif lainnya seperti hunian, perkebunan, hutan rakyat atau menjadi danau kaolin untuk objek pariwisata baru" (Informan 2, Wawancara 28 Juli 2017) .

Kajian terhadap berbagai relasi tiga hal tersebut kemudian mengarah pada percepatan penyusunan Perda Zonasi sebagai agenda setting perusahaan pertambangan dan pemerintah daerah. Agenda setting ini selanjutnya dikemas dalam berbagai aktivitas sebagai sumber pemberitaan media massa. Melalui pemberitaan yang terus menerus tentang pentingnya Perda Zonasi untuk menyelaraskan seluruh kepentingan dalam sektor pertambangan melalui media massa tersebut kemudian membentuk agenda publik. Sehingga dalam skema ini, media massa sesungguhnya hanya berfungsi sebagai mesin penyusun agenda pemerintah dan korporasi untuk mendapat dukungan dari publik. Hal tersebut dapat digambarkan di dalam gambar 1.

Alur pada gambar 1 menjadi varian lain dari pengembangan agenda setting media level satu digagas oleh McComb kemudian direvisi menjadi agenda setting media level dua. Varian agenda setting media baru ini lebih pelik karena mengandung dua anomali, yaitu:

Pertama, dalam memberitakan suatu isu (dalam hal ini pertambangan timah) media tidak memiliki agenda setting. Namun demikian, agenda setting media dapat dibentuk oleh perusahaan pertambangan melalui suatu relasi transaksional.

Kedua, agenda setting media dapat membentuk agenda sosial kemudian dapat mendorong kebijakan publik sebagai agenda pemerintah. Padahal dalam penelitian ini Perda zonasi sebagai agenda pemerintah juga merupakan agenda perusahaan pertambangan.

Kedua anomali tersebut dapat digambarkan sebagai kematian atau akhir dari agenda setting media. Pada bagian hulu, gatekeeper yang berfungsi menyeleksi berbagai isu pada agenda setting media tidak dapat memainkan perannya karena ruang redaksi media juga dikendalikan melalui suatu proses transaksional. Transaksional tersebut dapat berlangsung secara formal melalui kerja sama iklan atau secara informal melalui berbagai transaksional pada pekerja media saat melakukan liputan. Pengamatan silang yang dilakukan oleh Carpini dan Williams (dalam Bennett and Entman, 2010)

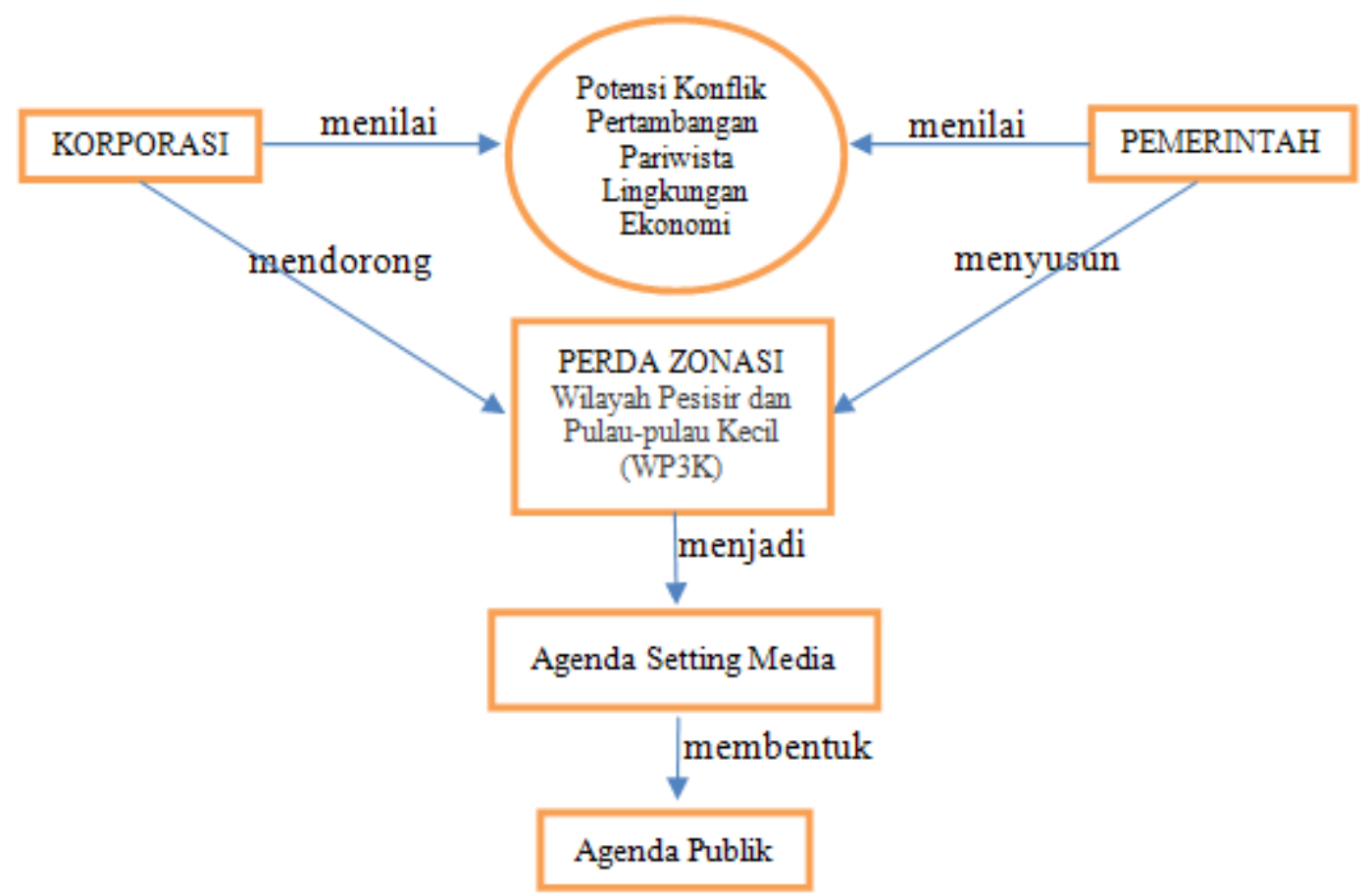

Sumber: Hasil Olahan Peneliti, 2017

Gambar 1 Alur Penyusunan Agenda Setting Korporasi sebagai Agenda Setting Media 
menyebut beberapa alasan pokok penyebab fenomena ini terjadi. Antara lain adanya perubahan struktural industri media, integrasi vertikal dan horisontal industri media, tekanan pencapaian ekonomi, munculnya pekerja media yang hanya memiliki keterikatan minim pada kode-kode etik jurnalistik, dan cara pandang bahwa lapangan jurnalisme dan pekerja biasa itu sama saja.

Sebagai industri, media massa adalah institusi ekonomi yang digerakkan oleh mekanisme pasar. Dalam perspektif ini, informasi adalah komoditas dan media adalah ruang atau tempat untuk menjajakan komoditi informasi. Iklan, kerja sama editorial atau praktik transaksional lainnya merupakan mekanisme yang disepakati kedua belah pihak secara institusional antara manajemen media dan manajemen korporasi yang saling menguntungkan. Atau transaksional juga dapat terjadi pada level individual antara seorang jurnalis dengan Humas korporasi. Relasi yang terjadi antara Humas dan Media mirip dengan model Imbalanced Comentalism Relationship.

Mengacu pada Darmastuti (2012) transaksional baru ini digambarkan sebagai Imbalanced Comentalism Relationship. Comentalism diambil dari prinsip relasi dua hewan yang hidup bersama, mereka tidak saling mengganggu walau tidak saling menguntungkan tapi tidak saling merugikan. Model hubungan Imbalanced Comentalisme Relationship dalam hal ini adalah hubungan Humas korporasi dengan media massa merupakan hubungan yang tidak saling merugikan walaupun belum tentu saling menguntungkan. Hubungan tersebut bersifat formal tapi dalam situasi kekeluargaan dan konteks bisnis. Pada praktiknya dapat dilihat dalam banyak bentuk. Antara lain Humas korporasi bekerja sama pemasangan iklan dengan media dengan kompensasi media memuat berita perusahaan tersebut. Secara teknis yang menyiapkan berita bukan media tetapi perusahaan yang bersangkutan dalam bentuk pressklaar.

Hubungan ini kendati dalam terlihat dalam bentuk kerja sama, namun pihak media tidak memiliki konsekuensi timbal balik. Hubungan keduanya saling menguntungkan, tapi berjalan tidak seimbang. Media masih berada pada posisi yang lebih menguntungkan karena telah mendapat kompensasi, tetapi pekerjaan jurnalis membuat berita disiapkan oleh pihak
Humas dan tidak ada kepastian jaminan berita akan dimuat oleh media bersangkutan. Padahal sebagai industri, media butuh iklan untuk bertahan hidup, sementara perusahaan butuh pemberitaan positif untuk kebaikan perusahaan. Posisi ini awalnya memang seperti saling membutuhkan, tetapi pada praktiknya berjalan tidak seimbang.

Namun secara spesifik dalam penelitian ini model Imbalanced Comentalism Relationship yang terjadi memiliki beberapa karakteristik spesifik. Karakterisktik spesifik tersebut terletak pada adanya muatan agenda setting korporasi yang selaras dengan agenda setting kebijakan pemerintah (goverment). Keselarasan dua agenda yang sama dari dua institusi yang berbeda tersebut berkolaborasi secara simetris membentuk agenda setting media. Proses simbiosis mutualismeyang sesungguhnya terjadi bukan antara Humas korporasi dengan media, tetapi antara korporasi dengan pemerintah. Relasi tersebut dapat dideskripsikan dalam dua model yaitu;

Pertama, relasikorporasidengan pemerintah bersifat saling koordinatif dan konsultatif. Korporasi memiliki aktivitas penambangan timah yang berimpitan dengan sektor lainnya hingga membutuhkan kepastian hukum adanya aturan zonasi untuk keamanan dan kepastian investasi untuk mengeksplorasi dan mengeksploitasi timah. Sedangkan pemerintah memiliki kewenangan dan kewajiban regulatif membuat peraturan zonasi untuk melindungi seluruh stakeholders pemangku kepentingan penambangan timah, baik di darat maupun di laut.

Kedua, relasi korporasi dengan media bersifat simetris mutualisme simbiosis. Perusahaan dan media saling membutuhkan karena itu harus saling menguntungkan. Karena saling menguntungkan harus seimbang bentuk kerja dan kompensasinya. Proses relasi tersebut dapat bersifat formal melalui suatu perjanjian bisnis. Namun dapat juga terselenggara secara tidak formal tetapi bersifat personal dalam suasana pertemanan dan kekeluargaan.

Mengacu pada informan 2, relasi dengan media sendiri dilakukan dengan model yang berbeda sesuai dengan reaksi masing-masing media. Dalam relasi yang beragam tersebut, reaksi media juga berbeda-beda. Ada media yang ditawarkan kerja sama iklan agar proses penyampaian agenda setting perusahaan dapat 
diterima sebagai agenda setting media. Namun ada juga media yang tidak ditawarkan kerja sama iklan yang melibatkan transaksi bisnis antar institusi tetapi transaksi yang bersifat personal dalam suasana pertemanan dan kekeluargaan.

"Prinsipnya semua media adalah mitra bagi Humas korporasi. Namun tidak semua media memberi respon yang sama terhadap agenda korporasi. Untuk media tertentu, dengan pertimbangan tertentu pula, diajak kerja sama dalam bentuk iklan atau advertotial. Namun media lainnya, cukup dengan pendekatan personal saja. Misi kitakan sama dengan pemerintah, bagaimana menambang selaras dengan sektor lainnya seperti pariwisata dan nelayan. Karena itu perlu diatur dengan sistem zona, satu sektor tidak boleh menafikan sektor lainnya. Semua bekerja pada sektor masing-masing untuk tujuan yang sama mesejahterakan masyarakat dan memajukan daerah. Ini agenda bersama, bukan saja agenda korporasi. Hanya saja media diperlukan sebagai sarana sosialisasi agar masyarakat memahami dan mendukung" (Informan 2, Wawancara 28 Juli 2017).

Penyusunan perda zonasi menjadi contoh yang ditemukan dalam penelitian ini sebagai titik pertemuan agenda bersama antara kepentingan perusahaan pertambangan dan kepentingan pemerintah. Sementara media sendiri, dalam konteks ini hadir dalam kapasitas sebagai institusi ekonomi. Media pada konteks ini, bukan institusi sosial-politik yang bekerja dengan muatan agenda politik seperti pada riset agenda setting media yang pernah dilakukan sebelumnya (Beltran, 2017, Santosa, 2017, Madani, 2011). Sebagai institusi ekonomi, media dikelola melalui prinsip pencapaian profit. Media tidak memiliki agenda untuk mendorong suatu perubahan sosial politik yang mendorong keluarnya suatu kebijakan baru seperti yang terjadi pada kasus Prita vs RS Omni International atau kasus Cecak vs Buaya (Lim, 2014; Nugroho, 2012).

Prinsip pencapaian profit menjadikan aktivitas media bersifat transaksional. Satu sisi, situasi tersebut terjadi karena tekanan persaingan yang ketat sesama media massa di Bangka Belitung. Hingga saat ini setidaknya ada 5 media massa di Bangka dan 2 media massa di Belitung. Namun pada sisi lain, media massa tersebut juga berkompetisi dengan media daring dan media sosial yang pertumbuhannya juga sangat cepat dan dinamis. Hingga saat ini tercatat setidaknya ada 14 media daring yang sama sekali tidak memiliki basis media cetak dan 1 media daring berbasis kantor berita nasional serta 1 media daring berbasis media cetak nasional. Selain itu, kehidupan di media

Tabel 1 Pemetaan Media Massa Cetak dan Media Daring di Bangka Belitung

\begin{tabular}{lllll}
\hline No & Media Massa Cetak & Media Massa Daring & Group & Wilayah \\
\hline 1 & Bangka Pos & http://bangka.tribunnews.com/ & Kompas & Bangka \\
2 & Babel Pos & http://babelpos.co/ & Jawa Pos & Bangka \\
3 & Rakyat Pos & http://www.rakyatpos.com/ & & Bangka \\
4 & Radar Bangka & http://www.radarbangka.co.id/ & Jawa Pos & Bangka \\
5 & Laspella & - & - & Bangka \\
6 & Pos Belitung & http://belitung.tribunnews.com/ & Kompas & Belitung \\
7 & Belitong Ekspress & https://belitongekspres.co.id/ & Jawa Pos & Belitung \\
\hline
\end{tabular}


Tabel 2 Daftar Media Daring di Bangka Belitung

\begin{tabular}{cl}
\hline No & \multicolumn{1}{c}{ Media Daring } \\
\hline 1 & http://www.antarababel.com/ \\
2 & http://www.rmolbabel.com/ \\
3 & http://terabasnews.com/ \\
4 & http://reportasebangka.com/ \\
5 & http://www.lensabangkabelitung.com/ \\
6 & http://beritabangka.com/ \\
7 & http://www.korankite.com/ \\
8 & https://beritababel.com/ \\
9 & http://www.bangkaterkini.com/ \\
10 & http://bangkatimes.com/ \\
11 & http://mediababel-daring.com/ \\
12 & http://kabarkite.com/ \\
13 & https://www.aksibabel.com/ \\
14 & http://klikbabel.com/ \\
15 & http://www.trawangnews.com/ \\
16 & http://kabarbangka.com/ \\
\hline
\end{tabular}

Sumber: Hasil Olahan Peneliti, 2017

sosial juga merupakan sektor yang sering dijadikan sumber informasi bagi khalayak. Salah satu grup diskusi terbuka di media sosial jenis facebook cukup aktif mendiskusikan berbagai tema tentang Belitung, termasuk tema tentang pertambangan. Pemetaan tersebut dapat dilihat dalam tabel 1 dan 2.

Beragam dan dinamisnya aktivitas dari berbagai media massa dan hiper-aktif/hiperinteraktif dalam media sosial atau media daring tersebut merupakan faktor ekternal yang dapat mematikan agenda setting media. Aktivitas dan hiper-aktif/hiper-interaktif tersebut turut mem-porakporanda-kan skema agenda setting media yang sudah mapan selama ini. Sebab dalam kehidupan media baru yang marak saat ini seorang netizen dapat bertindak sebagai pencari informasi, memproduksi informasi, memanipulasi informasi, memodifikasi informasi, menyeleksi informasi sekaligus dapat menjadi penyebar informasi. Media baru menjadi tema paling baru yang turut menentukan konstruksi sosial melalui penyebaran opini lewat media baru. Pada awalnya, semua media adalah media baru (Gitelman, 2006; Zielinski, 2009). Mesin ketik, telegraf optic, album rekaman vinil, tape delapan-track atau walkman, hari ini merupakan jenis media kuno. Namun jenis media tersebut tidak selalu kuno, karena masih digunakan oleh sebagai media hingga saat ini. Hal ini menjadi faktor lain untuk dipelajari dan diteliti guna memahami makna bahwa agar dapat disebut menjadi media baru, hal itu terkait dengan waktu dan budaya.

Kehadiran media baru saat ini identik dengan berbagai jenis media yang digunakan untuk menyebarkan informasi berbasis Internet. Kemudian secara spesifik media baru identik dengan penggunaan media sosial dalam berbagai jenisnya seperti group diskusi tertutup seperti WhatsApp, Line, Blackberry Massenger atau media sosial terbuka dengan karakteristik berbeda seperti twitter, facebook dan blog.

$$
\text { Mengacu pada Nasrullah (2014) }
$$

berbagai jenis media sosial tersebut memiliki karakteristik (1) intertextuality, artinya setiap teks dan beberapa teks lainnya dapat saling tertaut dan 'berbicara'. Oleh sebab itu, satu teks terkadang hanya dapat 'dibaca' dan dipahami maknanya bila membaca terlebih dahulu teks lainnya. Lebih jauh, jaringan antar teks tersebut dapat menciptakan konteks. (2) ndaringarity, artinya setiap pergerakan pembicaraan tidak dapat diprediksi secara lurus dan linear. Satu topik pembicaraan dapat saja berkembang dan melahirkan topik baru lainnya. (3) blurring the reader/writer distinction, artinya ada pembeda yang kabur antara pembaca dan penulis. Dapat saja seorang netizen awalnya sebagai konsumen informasi. Namun informasi tersebut dikemas ulang kemudian didistribusikan kembali menjadi konten baru. Pada saat bersamaan reproduksi informasi tersebut menjadi pembatas yang halus antara konsumen dan produsen informasi. (4) multimedianess, artinya media sosial bersifat konvergensi yang dapat memuat teks, audio, video dan sebagainya. (5) no Gatekeeper, artinya dalam media sosial tidak ada 'penjaga gawang' yang berfungsi menyeleksi infomasi yang masuk dan keluar di media sosial sebagaimana yang terjadi pada media mainstream. (6) ephemerality, artinya teks di media sosial bersifat tidak stabil. Atas kehendak sendiri, suatu teks di media sosial dapat dihapus baik disengaja maupun tidak disengaja.

Dengan karakteristik tersebut, aktivitas di media sosial memberi kemungkinan pada setiap orang untuk saling berbagi informasi secara luas atau terbatas pada orang yang dikehendakinya. Melalui karakteristik salurannya, media sosial dapat mengidentifikasi arah pesannya (Kent, 
2010) atau menggunakan alat khusus seperti Facebook atau Twitter untuk menunjukkan model interaksinya (Howard, and Parks, 2012). Interaksi dan penyebaran informasi tersebut dapat diperoleh dari berbagai sumber di Internet atau memproduksinya sendiri. Karakteristik dan aktivitas di media sosial yang spesifik dan dinamis tersebut merupakan faktor di luar media massa yang dapat mematikan agenda setting media.

Dalam konteks penelitian ini, kehadiran media baru mengubah tatanan proses agenda setting media yang telah berlangsung selama ini. Pada era media baru berbasis teknologi dan Internet juga telah menempatkan media massa (terutama cetak) mengkonstruksikan agenda setting media (Rianto, 2010). Namun demikian, bila agenda setting media sebelum kemunculan media baru terkait dengan persoalan politik (Khotimah, 2002; Luo, 2014; Salman, 2016) dan kebijakan (Irwansyah dan Agustina, 2017; Nasionalita, 2015; Cindoswari, Abidin, dan Herman, 2017) kehadiran media baru tersebut lebih luas terkait dengan agenda setting korporasi.

\section{SIMPULAN}

Perusahaan pertambangan timah di Bangka Belitung memiliki agenda setting agar Perda Zonasi disyahkan. Agenda setting perusahaan ini sama dengan agenda pemerintah daerah. Perda Zonasi dinilai menjadi agenda utama karena merupakan dasar hukum untuk mempertemukan berbagai sektor kepentingan terkait pertambangan. Untuk memperkuat agenda setting tersebut diperlukan pemberitaan media massa. Perusahaan pertambangan mencari sejumlah tokoh masyarakat, akademisi atau politisi untuk dijadikan narasumber pemberitaan. Pada saat yang bersamaan, media massa sebagai industri tidak memiliki agenda setting terkait persoalan pertambangan. Sebaliknya, sebagai industri media massa lebih berorientasi profit sehingga cenderung bersifat transaksional melalui berbagai kerjasama iklan dan pemberitaan.

Sehingga, agenda setting media tidak sepenuhnya menjelaskan bagaimana media menyusun agenda mereka, kemudian menjadi agenda publik dan selanjutnya menjadi sebuah kebijakan sebagai produk agenda negara (pemerintah). Penelitian ini menemukan bahwa agenda media dapat dipengaruhi atau ditentukan oleh agenda pihak lain di luar institusi media massa yang memiliki kepentingan tertentu. Dalam penelitian ini agenda yang dimaksud tersebut adalah agenda korporasi pertambangan dan agenda pemerintah untuk menyusun Perda Zonasi dengan menekan potensi konflik yang muncul. Dua insititusi berbeda tetapi memiliki satu agenda bersama memberi pengaruh dalam proses menyusun agenda setting media.

Pengaruh tersebut terjadi melalui berbagai relasi berbasis transaksional antara perusahaan pertambangan dengan media massa lokal. Model transaksi tersebut dilakukan dengan sebuah perjanjian kerjasama antar institusional dalam bentuk iklan dan pemberitaan atau kerjasama personal dalam suatu iklim perkawanan, persahabatan dan kekeluargaan. Dalam perspektif ini, media massa merupakan representasi institusi ekonomi yang memiliki orientasi mencari keuntungan untuk keberlangsungan perusahaan media melalui berbagai kerjasama yang saling menguntungkan. Media massa yang awalnya tidak memiliki agenda setting khusus dalam pemberitaan terkait isu pertambangan (khususnya isu tentang Perda Zonasi) menjadi memiliki agenda karena terikat dengan kerjasama iklan dan pemberitaan.

Kehadiran media sosial atau media daring berbasis Internet sebagai media baru telah menempatkan siapa saja dapat mencari, memproduksi, memanipulasi, mengkomodifikasi dan mendistribusikan informasi yang mereka pilih. Aktivitas yang dinamis dan hyperactive netizen di media sosial tersebut merupakan faktor eksternal lainnya yang turut memberi pengaruh terhadap alur skema agenda setting media. Kondisi-kondisi tersebut merubuhkan fungsi gatekepeer sebagai hulu pangkal beroperasinya agenda setting media. Situasi ini kemudian yang digambarkan sebagai potret akhir agenda setting media.

\section{DAFTAR PUSTAKA}

Ardhoyo, T. E. (2013). Peran dan strategi humas (public relations) dalam mempromosikan produk perusahaan. Jurnal Ilmiah Widya, $1,(1), 15-21$.

Astuty, S., dkk. (2017). Analisis fungsi dan peran humas dalam upaya implementasi good governance (studi pada bagian humas sekretariat daerah kota Banjarmasin). 
Meta Communication: Journal Of Communication Studies, 2, (1), 100-118.

Beltran, J. V. (2017). The emergence of the philippine "anti-media": the duterte factor. Jurnal Ilmu Komunikasi, 14 (1), 61-74.

Bernadeth, H., Paranoan, D. B., Djumlani, A. (2014). Peranan humas dalam membangun citra pemerintahan kabupaten Kutai Barat. Ejournal Administrasi Reform, 2, (3), 2054-2067.

Bodgan, R. \& Steven, J. T. (1998). Introduction to qualitative research methods: a phenomenological approach to social sciences. New York: John Willey and Sons.

Carpini, D. M. \& Williams, B. (2010). Let us infotain you: politics in the new media environment. Dalam bennett, lance $w$ and entman, robert $m$, mediated politics: communication in the future of democracy (pp. 160-81). New York: Cambridge University Press.

Cindoswari, A. R., Abidin, S., dan Herman, H. (2017). Agenda setting harian tribun batam dalam pemberitaan implementasi kawasan ekonomi khusus. Commed Jurnal Komunikasi Dan Media, 2, (1), 1-12.

Cutlip, SM., Center, A. \& Broom, GM. (2009). Effective public relations. New Jersey: Prentic-Hall.

Darmastuti, R. (2012). Media relations: konsep, strategi dan aplikasi. Yogyakarta: Penerbit Andi.

Farihanto, M. N. (2014). Teman tapi mesra humas dan wartawan (studi kasus strategi hubungan media di bidang humas dan protokoler universitas ahmad dahlan). Jurnal Komunikasi Profetik, 7, (2), 53-63.

Febriyansyah, A. R., Christin, M., dan Imran, A. I. (2016). Strategi media relations pt. pelabuhan tanjung priok dalam menanggapi krisis. Jurnal Kajian Komunikasi, 4 (2), $229-242$.

Forttal gelar aksi damai tolak tambang laut, (2013, Agustus 5) dalam belitongekspres. co.id, diakses 10 Agustus 2017. https:// belitongekspres.co.id/forttal-gelar-aksidamai-tolak-tambang-laut/

Gitelman, L. (2006). Always alreadynew media, history, and the data of culture. London: The MIT Press.

Griffin, E. M. (2015). A first look at communication theory. McGraw Hill
Education.

Hernawan, W. dan Muniroh (2014). Strategi public relations dalam membentuk opini publik tentang pencitraan di pt. bukit asam (persero) tbk. unit pelabuhan tarahanbandar lampung. Kom \& Realitas Sosial Jurnal Ilmu Komunikasi, 4, (2), 174-189.

Howard, P. N. \& Parks, M. R. (2012). Social media and political change: capacity, constraint, and consequence. Journal Of Communication, 62, 359-362.

Idris, I. K. (2014). Peran humas pemerintah di era keterbukaan informasi (analisis isi permenpan-rb no. 6 tahun 2014 tentang jabatan fungsional pranata humas dan angka kreditnya). Jurnal Universitas Paramadina, 11, (3), 1146-1163.

Iriantara, Y. (2010). Media relations: konsep, pendekatan, dan praktik. Bandung: Simbioasa Rekatama.

Irwansyah dan Agustina, T. (2017). Peran agenda setting media massa dalam kebijakan penetapan harga eceran tertinggi (het) beras oleh pemerintah. Jurnal Ilmu Politik Dan Komunikasi, 7, (2), 227-236.

Ishak, A. (2012). Peran public relations dalam komunikasi organisasi. Jurnal Komunikasi, 1, (4), 373-380.

Kent, M. L. (2010). Directions in social media for professional and scholars dalam robert $l$ heath (eds), the sage handbook of public relations (pp. 643-656). Thousand Oaks: Sage Publications.

Khotimah, E. (2002). Media massa dan labelling terorisme (suatu analisis terhadap skenario agenda setting global dan nasional). Mimbar, 18, (4), 399-413.

Lim, M. (2014). Many clicks but little sticks: social media activism in Indonesia. Journal Of Contemporary Asia. 43 (4), 636-657.

Lubis, E. E. (2012). Peran humas dalam membentuk citra pemerintah. Jurnal Ilmu Administrasi Negara, 12, (1), 1-60.

Luo, Y. (2014). The internet and agenda setting in china: the influence of daring public opinion on media coverage and government policy. International Journal Of Communication, 8-1289-1312.

Madani, M. (2011). Agenda setting pengelolaan sampah pasar di kota makassar. Otoritas, 1, (1), 11-24.

Maman, Kartini, D. S., Yuningsih, N. Y. (2016). 
Agenda setting dalam proses pembentukan kabupaten bandung barat. Jurnal Ilmu Pemerintahan, 2, (1), 66-94.

McCombs, M. (2005). A look at agendasetting: past, present and future. Journalism Studies, 6 (4), 543-557.

(2016). Agenda setting; reading on media, public opinion, and policymaking. New York: Routledge.

Nasionalita, K. (2015). Relevansi teori agenda setting dalam dunia tanpa batas. Jurnal Ilmiah Komunikasi Makna, 5, (2), 156-164.

Nasrullah, R. (2014). Teori dan riset media siber (cybermedia). Jakarta: Kencana.

Nokia, Sony, Motorola, LG, dan Blackberry Mengaku Gunakan Timah dari-Tambang Ilegal Pulau-Bangka, (2013, Agustus 5) dalam mongabay.co.id, diakses 3 Juni 2017, http://www.mongabay.co.id/2013/08/05/ nokia-sony-motorola-lg-blackberrymengaku-gunakan-timah-dari-tambangilegal-pulau-bangka/.

Nugroho, Y. \& Syarief, S. S. (2012). Beyond click-activism? new media and political processes in contemporary indonesia. Jakarta: Friedrich Ebert Stiftung.

Pamudji, M. T., dkk (2016), analisis pembentukan harga di bursa timah indonesia dan dunia. Jakarta: Pusat Data dan Teknologi Informasi Kementerian Energi dan Sumber Daya Mineral.

Pembayun, J. K. (2015). Konglomerasi media dan dampaknya pada pilpres 2014. Jurnal Interaksi, 4, (2), 109-116.

Pramono, (2016). Deskrepansi agenda media dengan agenda publik: studi agenda setting harian radar madiun terhadap mahasiswa jurusan ilmu komunikasi fisip univ. muhammadiyah ponorogo. Jurnal Aristo, 4, (2), 14-30.

Pruitt, D. G. \& Rubin, J. Z. (1986). Social conflict: escalation, stalemate, and settlement. New York: Random House.

Rahmat, A. \& Bakti, I. (2016). Kinerja hubungan masyarakat (humas) pemerintah daerah kabupaten dan kota di jawa barat. Jurnal
Kajian Komunikasi, 4, (2), 133 - 141.

Rianto, P. (2010). Opini publik, agenda setting, dan kebijakan public. Jurnal Komunikasi, 5, (1), 31-40.

Salman, A. (2016). Social media and agenda setting: implications on political agenda. Jurnal Komunikasi Malaysian Journal of Communication, 32 (1), 401-414.

Santosa, B. A. (2017). Peran media massa dalam mencegah konflik. Jurnal Aspikom, 3, (2), 199-214.

Sarohmawati, S. \& Ashaf, A.F. (2017). Membingkai praktik politik dan identitas dalam media siber Indonesia. Jurnal Metakom, 1, (2), 59-76.

Setyowati, R. M. (2011). Wikileaks dan agenda setting media. The Messenger, 2 (2), 28-32.

Syahputra, I. (2013). Rezim media. Jakarta: Gramedia.

Theaker, A. (2012). The public relations handbook. Londong: Rotledge.

Undang-Undang Nomor 27 tahun 2007 tentang pengelolaan Wilayah Pesisir dan Pulaupulau Kecil (WP3K).

Vivian, J. (2017). The media of mass communication. New York: Pearson.

Wimmer, R. D. \& Dominick, J. R. (2014). Mass media research an introduction. Wadsworth, Cengage Learning.

Yuningsih, A. (2006). Peran strategis profesi public relations dalam membangun kemitraan berbasis nilai spiritual studi deskriptif analitis terhadap peran strategis profesi public relations sebagai fasilitator kemitraan antara pemerintah, komunitas sipil dan komunitas bisnis dalam meningkatkan indeks pembangunan manusia (ipm) di jawa barat. Mimbar, 22, (4), 496-520.

Yustisia, S. (2010). Citizen journalism melawan mainstream media. The Messenger, 2(1), $1-9$

Zielinski, S. (2009). Deep time of the media: toward an archaeology of hearing and seeing by technical means. Cambridge, MA: MIT Press. 